\title{
PERILAKU PENCARIAN INFORMASI PADA MAHASISWA STRATA SATU (S1) PENDIDIKAN BIOLOGI ANGKATAN 18 UNIVERSITAS SULTAN AGENG TIRTAYASA
}

\author{
Rifni Raihana \\ Universitas Indonesia \\ Email : rifniraihana@gmail.com \\ Taufik Asmiyanto \\ Universitas Indonesia \\ Email : taufik.asmiyanto@gmail.com
}

\begin{abstract}
Everyone has information needs and information-seeking behavior. This study aims to describe college students' information-seeking behavior in UNTIRTA's Biology Education study program class of 18. This research used a descriptive quantitative approach. The researcher used the information-seeking behavior model developed by David Ellis. The questionnaire distributed was a Likert scale with a range of 5. Respondents numbered 34 people. The results showed that the students knew their information needs. They conducted the process of starting up to extracting during the search process. It can be concluded that the Biology Education student class 18 has an awareness of information needs and can search, sort, and process information according to their needs
\end{abstract}

Keywords : information needs, information seeking behavior, UNTIRTA

\begin{abstract}
Abstrak: Setiap orang memiliki kebutuhan informasi dan memiliki perilaku pencarian informasi. Penelitian ini bertujuan untuk mendeskripsikan perilaku pencarian informasi yang dilakukan oleh mahasiswa program studi Pendidikan Biologi angkatan 18 UNTIRTA. Penelitian ini adalah penelitian kuantitatif deskriptif. Penulis menggunakan model perilaku pencarian yang dikembangkan oleh David Ellis. Kuesioner yang disebarkan adalah skala likert dengan rentang 5. Responden berjumlah 34 orang. Dari hasil analisis kuesioner, mahasiswa Pendidikan Biologi angkatan 18 UNTIRTA tahu akan kebutuhan informasinya. Mahasiswa Pendidikan Biologi angkatan 28 UNTIRTA melakukan proses starting hingga extracting selama proses pencarian. Dapat disimpulkan bahwa mahasiswa Pendidikan Biologi angkatan 18 UNTIRTA memiliki kesadaraan akan kebuutuhan informasi dan mampu mencari, memilah, dan mengolah informasi sesuai dengan kebutuhannya
\end{abstract}

Kata Kunci: kebutuhan informasi, perilaku pencarian informasi, UNTIRTA 
Rifni Raihana, Taufik Asmiyanto, Perilaku Pencarian Informasi Pada ...

\section{PENDAHULUAN}

Sebagaimana manusia membutuhkan air, udara, makanan, obat maupun tempat berlindung selalu ada dalam diri manusia akan kebutuhan informasi. Orang yang disediakan informasi secara memadai memungkinkan orang tersebut menyelesaikan permasalahannya dengan lebih baik ${ }^{1}$. Batley menyatakan bahwa dalam konteks ilmu informasi, kebutuhan informasi muncul ketika sesorang menyadari bahwa mereka tidak memiliki atau kekurangan pengetahuan atau pemahaman untuk mencapai tujuan, menjawab pertanyaan dan lain sebagainya ${ }^{2}$. Penelitian terdahulu tentang kebutuhan informasi di perguruan tinggi sebagai contoh di Fakultas Hukum di Universitas Nirma menjelaskan bahwa praktisi hukum memerlukan informasi guna melaksanakan pengajaran dan penelitian. Buku dan laporan hukum adalah informasi yang dinilai penting. Dari hasil penelitian tersebut, dapat dilihat bahwa informasi berperan penting dalam proses pembelajaran di Fakultas Hukum Universitas Nirma. Buku dan laporan hukum adalah sebagai sumber pembelajaran. ${ }^{3}$

UU Nomor 20 Tahun 2003 tentang sistem pendidikan nasional pasal 1 ayat 20 menjelaskan bahwa Pembelajaran merupakan proses interaksi antara peserta didik dengan pendidik dan sumber belajar pada suatu lingkungan belajar. ${ }^{4}$ Kebutuhan informasi dapat dikategorikan secara umum menjadi kebutuhan fisiologis, kebutuhan emosional dan kebutuhan kognitif. Guna memenuhi kebutuhan informasi, orang tersebut akan melaksanakan pencarian informasi. ${ }^{5}$ Proses pembelajaran juga terjadi di Fakultas Keguruan dan Ilmu Pendidikan

\footnotetext{
${ }^{1}$ Essam Mansour, "Profiling Information Needs and Behaviour of Syrian Refugees Displaced to Egypt: An Exploratory Study," Information and Learning Science 119, no. 3-4 (2018): 161-82, https://doi.org/10.1108/ILS-08-2017-0088.

${ }^{2}$ Hadira Latiar, "Analisis Kebutuhan Dan Perilaku Pencarian Informasi Mahasiswa Difabel UIN Sunan Kalijaga Yogyakarta," LIBRARIA: Jurnal Perpustakaan 6, no. 2 (December 13, 2018): 239, https://doi.org/10.21043/libraria.v6i2.2767.

${ }^{3}$ Atul Ashokbhai Bhatt, "Information Needs, Perceptions and Quests of Law Faculty in the Digital Era," Electronic Library 32, no. 5 (2014): 659-69, https://doi.org/10.1108/EL-11-2012-0152.

${ }^{4}$ Imam Fitri Rahmadi, Khaerudin Khaerudin, and Cecep Kustandi, "Kebutuhan Sumber Belajar Mahasiswa Yang Mendukung Pembelajaran Berbasis Teknologi Informasi Dan Komunikasi Di Perguruan Tinggi," JTP - Jurnal Teknologi Pendidikan 20, no. 2 (2018): 120-36, https://doi.org/10.21009/jtp.v20i2.8620.

${ }^{5}$ Reijo Savolainen, "Expectancy-Value Beliefs and Information Needs as Motivators for TaskBased Information Seeking," Journal of Documentation 68, no. 4 (2012): 492-511, https://doi.org/10.1108/00220411211239075.
} 
Porgram studi Pendidikan Biologi Universitas Sultan Ageng Tirtayasa (UNTIRTA). Tenaga pendidik dan mahasiswa serta sivitas akademika di program studi ini juga tentunya memiliki kebutuhan informasi. kebutuhan informasi dalam hal ini adalah sumber pembelajaran.

Sumber pembelajaran memiliki kedudukan dan peran yang vital atas terjadinya proses pembelajaran. Sumber belajar yang lengkap, relevan, dan mutakhir dapat mendorong terwujudnya pembelajaran yang berkualitas di perguruan tinggi. Terlebih mengingat bahwa pada perguruan tinggi menggunakan sistem belajar orang dewasa (andragogy), sehingga mahasiswa secara mandiri dituntut proaktif dalam berinteraksi dengan sumber belajar. Semakin lengkap sumber belajar yang ada akan semakin memudahkan mahasiswa dalam belajar dan mendorong ketercapaian tujuan pembelajaran. ${ }^{6}$ Salah satu mahasiswa yang ada di program studi Pendidikan Biologi UNTIRTA adalah angkatan 18.

Penelitian ini fokus pada perilaku pencarian informasi yang dilakukan oleh mahasiswa program studi Pendidikan Biologi angkatan 18. Hasil dari penelitian ini diharapkan dapat bermanfaat bagi pengembangan ilmu perpustakaan dan Perpustakaan Universitas Sultan Ageng Tirtayasa dalam melayani sivitas akademika khususnya mahasiswa program studi pendidikan biologi angkatan 18 .

\section{METODE PENELITIAN}

Dalam penelitian ini penulis menggunakan pendekatan kuantitatif deskriptif. Penelitian kuantitatif banyak dituntut menggunakan angka, mulai dari pengumpulan data, penafsiran terhadap data tersebut, serta penampilan dari hasilnya. Penelitian kuantitatif merupakan penelitian yang menggunakan upaya Pengumpulan data numerik dan menggunakan logika deduktif dalam pengembangan dan pengujian teori. Jenis penelitian ini adalah kuantitatif deskriptif . Penelitian deskriptif merupakan penelitian yang mengumpulkan data berdasarkan faktor-faktor yang menjadi pendukung terhadap objek penelitian,

\footnotetext{
${ }^{6}$ Rahmadi, Khaerudin, and Kustandi, "Kebutuhan Sumber Belajar Mahasiswa Yang Mendukung Pembelajaran Berbasis Teknologi Informasi Dan Komunikasi Di Perguruan Tinggi."
} 
Rifni Raihana, Taufik Asmiyanto, Perilaku Pencarian Informasi Pada ...

kemudian menganalisa faktor- faktor tersebut untuk dicari peranannya. ${ }^{7}$

Populasi dari penelitian ini adalah Seluruh mahasiswa Fakultas Keguruan dan Ilmu Pendidikan Porgram studi Pendidikan Biologi Universitas Sultan Ageng Tirtayasa angkatan 18. Untuk penelitian metode deskriptif, minimal sampel adalah $10 \%$ populasi, untuk populasi yang relatif kecil minimal $20 \%$, sedangkan untuk penelitian korelasi diperlukan sampel sebesar 30 responden $^{8}$. Sampel dari penelitian ini adalah 20 persen dari 102 Mahasiswa pendidikan Biologi UNTIRTA angkatan 18. Penulis akan menyebarkan kuesioner skala likert dengan rentang 1-5 sebanyak 14 pernyataan melalui google form kepada 102 Mahasiswa pendidikan Biologi UNTIRTA angkatan 18. Penulis menggunakan model perilaku pencarian informasi yang dikembangkan oleh David Ellis dan mengembangkannya sebagai instrument dalam kuesioner penelitian ini.

\section{KAJIAN TEORI}

\section{Sumber pembelajaran}

Secara etimologis, sumber belajar terdiri dari dua kata yaitu sumber dan belajar. Setiap kata tersebut mengandung makna tersendiri. Disiplin ilmu Teknologi Pendidikan menjelaskan sumber (resource) sebagai asal yang mendukung terjadinya belajar, termasuk sistem pelayanan, bahan pembelajaran, dan lingkungan Sedangkan belajar (learning) diartikan sebagai perubahan yang relatif permanen dalam pengetahuan, perilaku, atau sikap seseorang karena pengalaman. Ketika dua definisi tersebut digabungkan, maka definisi sumber belajar adalah asal atau sesuatu yang dapat mendukung terjadinya perubahan yang relatif permanen pada pengetahuan, perilaku, atau sikap seseorang karena suatu pengalaman interaksi yang terjadi selama proses belajar, seperti menanggapi, menafsirkan, merespon,dan mengambil pelajaran dari suatu umpan balik. Secara

\footnotetext{
${ }^{7}$ Luthfi Hanif and Ika Krismayani, "Relevansi Ketersediaan Koleksi Terhadap Pemenuhan Kebutuhan Informasi Mahasiswa Di Perpustakaan Pusat Universitas Pgri Semarang," Jurnal Ilmu $\begin{array}{lllll}\text { Perpustakaan } & 7, & \text { no. } & 2 & \text { (2018): }\end{array}$ https://ejournal3.undip.ac.id/index.php/jip/article/view/22905.

${ }^{8}$ Idrus Alwi, "Kriteria Empirik Dalam Menentukan Ukuran Sampel Pada Pengujian Hipotesis Statistika Dan Analisis Butir," Formatif: Jurnal Ilmiah Pendidikan MIPA 2, no. 2 (August 5, 2015), https://doi.org/10.30998/formatif.v2i2.95.
} 
terminologis, menurut Association for Educational Communication and Technology (AECT), sumber belajar yakni semua sumber termasuk data, orang, dan benda yang dapat dimanfaatkan untuk belajar, secara terpisah maupun terkombinasi, demi tercapainya tujuan pembelajaran. ${ }^{9}$

\section{Kebutuhan Informasi}

Terdapat 5 fungsi informasi dalam menunjang implementasi tri dharma perguruan tinggi yakni :

1. Fungsi fact finding yaitu informasi yang dibutuhkan seseorang untuk menjawab pertanyaan tertentu.

2. Fungsi current awareness yaitu informasi yang dibutuhkan seseorang agar dapat mengikuti perkembangan mutakhir.

3. Fungsi research yaitu seseorang membutuhkan informasi dalam bidang tertentu secara lengkap dan mendalam.

4. Fungsi briefing yaitu informasi yang dibutuhkan seseorang mengenai topik tertentu secara ringkas dan sepintas.

5. Fungsi stimulus yaitu informasi yang dibutuhkan seseorang untuk merangsang ide-ide baru. ${ }^{10}$

Sehingga informasi dibutuhkan oleh semua sivitas akademika termasuk mahasiswa. Kebutuhan informasi adalah perkembangan dari kesadaran yang samar dari sesuatu yang telah dipergunakan dan berujung pada menemukan informasi yang bermafaat kontribusinya pada pemahaman dan pemaknaan ${ }^{11}$.

Kebutuhan informasi seseorang bergantung kepada 10 (sepuluh) hal yang dapat dijelaskan sebagai berikut

1. Work activity (aktivitas pekerja)

2. Discipline/ Field/Area of interest (Disiplin/lapangan/area ketertarikan)

3. Availability of facilities (Ketersediaan fasilitas)

${ }^{9}$ Rahmadi, Khaerudin, and Kustandi, "Kebutuhan Sumber Belajar Mahasiswa Yang Mendukung Pembelajaran Berbasis Teknologi Informasi Dan Komunikasi Di Perguruan Tinggi."

10 Alimin Tawaf; Khaidir, "Kebutuhan Informasi Manusia: Sebuah Pendekatan Kepustakaan," Kutubkhanah 15, no. 1 (June 2, 2012): 50-59, http://ejournal.uinsuska.ac.id/index.php/Kutubkhanah/article/view/249.

${ }^{11}$ Mansour, "Profiling Information Needs and Behaviour of Syrian Refugees Displaced to Egypt: An Exploratory Study." 
Rifni Raihana, Taufik Asmiyanto, Perilaku Pencarian Informasi Pada ...

4. Hierarchical position of individuals (Posisi hirarki seorang individu)

5. Motivation factors for information needs (faktor motivasi terhadap kebutuhan informasi)

6. Need to take a decision (kebutuhan untuk membuat keputusan)

7. Need to seek new ideas (kebutuhan dalam mencari ide baru)

8. Need to validate the correct ones (kebutuhan untuk memvalidasi kebenaran)

9. Need to make professional contributions (kebutuhan untuk membuat kontribusi yang professional)

10. Need to establish priority for discovery etc (kebutuhan untuk membangun prioritas dalam penemuan dan sebagainya). ${ }^{12}$

\section{Faktor Kebutuhan Informasi}

Faktor-faktor dalam kebutuhan informasi dapat dijelaskan sebagai berikut:

1. Kebutuhan kognitif : kebutuhan yang dirgunakan oleh seseorang untuk memperkuat dan menambah informasi, dan pengetahuan serta pemahaman untuk menguasai lingkungannya.

2. Kebutuhan afektif : kebutuhan yang berhubungan dengan hal yang menyenangkan yang memberi kekuatan estetis, serta pengalaman emosional.

3. Kebutuhan integrasi personal : kebutuhan untuk memperkuat kredibilitas diri, kepercayaan serta stabilitas dan status dari seorang individu.

4. Kebutuhan integrasi sosial : menjadi kebutuhan yang erat kaitannya dengan keinginan bergabung dengan orang lain.

5. Kebutuhan berkhayal : menjadi kebutuhan dalam pencarian hiburan. ${ }^{13}$

\section{Perilaku Pencarian}

Perilaku pencarian merupakan konsekuensi dari perasaan kebutuhan atas informasi, yang kemungkinan seseorang akan melakukan permintaan baik formal

\footnotetext{
12 Tawaf; Khaidir, "Kebutuhan Informasi Manusia: Sebuah Pendekatan Kepustakaan."

13 Dina Rahma Ningrum, Choirul Saleh, and Widia Permana Jurusan Administras Publik, "PENGARUH KEBUTUHAN INFORMASI PEMUSTAKA TERHADAP PENGEMBANGAN KOLEKSI BUKU TERCETAK PADA PERPUSTAKAAN UNIVERSITAS BRAWIJAYA (Studi Pada Mahasiswa S1 Jurusan Administrasi Publik Universitas Brawijaya)," Jap) 3, no. 5 (n.d.): 782, http://administrasipublik.studentjournal.ub.ac.id/index.php/jap/article/view/865.
} 
maupun informal dari sumber informasi atau jasa informasi guna memuaskan kebutuhannya. ${ }^{14}$ Pencarian informasi sangat dipengaruhi oleh kebutuhan informasi yang diinginkan oleh pengguna, semakin tinggi kebutuhan akan informasi yang diinginkannya, maka semakin tinggi pula pencarian informasi yang dilakukan oleh pengguna perpustakaan. ${ }^{15}$

\section{Model Perilaku Pencarian Pengguna}

Terdapat enam model perilaku pencarian informasi yang dikembangkan oleh David Ellis yaitu starting, chaining, browsing, differentiating, monitoring dan extracting yang dapat dijabarkan sebagai berikut :

1. Starting : terdiri dari kegiatan atau aktivitas yang memulai terjadinya kegiatan pencarian informasi.

2. Chaining : kegiatan mengikuti rangkaian sitasi, pengutipan atau bentukbentuk perujukan antar dokumen yang satu dengan yang lainnya.

3. Browsing : pencarian secara acak, mencari tetapi dengan agak terarah, di wilayah-wilayah yang dianggap punya potensi terhadap informasi yang dibutuhkan.

4. Differentiating : pemilahan, menggunakan ciri-ciri di dalam sumber informasi sebagai acuan dasar untuk memeriksa kualitas ataupun isi informasi.

5. Monitoring : memantau perkembangan dengan memfokuskan diri pada beberapa sumber terpilih.

6. Extracting : secara sistematis menggali di satu sumber untuk mengambil informasi yang dianggap penting. ${ }^{16}$

\section{HASIL PENELITIAN DAN PEMBAHASAN}

Hasil Pada tanggal 29 Maret 2020 Penulis menyebarkan kuesioner online google form kepada mahasiwa pendidikan biologi UNTIRTA angkatan 18.

\footnotetext{
${ }^{14}$ Mansour, "Profiling Information Needs and Behaviour of Syrian Refugees Displaced to Egypt: An Exploratory Study."

15 Yuni Rahmah and Elva Rahmah, "Perilaku Pencarian Informasi Generasi Milenial Untuk Memenuhi Kebutuhan Informasi Mahasiswa Universitas Negeri Padang," Ilmu Informasi Perpustakaan Dan Kearsipan 8, no. 1 (October 29, 2019): 562, https://doi.org/10.24036/1074880934.

${ }^{16}$ Rahmah and Rahmah.
} 
Rifni Raihana, Taufik Asmiyanto, Perilaku Pencarian Informasi Pada ...

Kuesioner berbentuk skala likert dalam rentang 1-5 dengan poin penilaian Sangat Tidak setuju, tidak setuju, cukup setuju, setuju dan sangat setuju. Sebanyak 14 pernyataan tentang perilaku pencarian informasi disebarkan untuk diukur. Dari 102 Mahasiswa Pendidikan Biologi di Fakultas Keguruan dan Ilmu Pendidikan di Univeristas Sultan Ageng Tirtayasa (UNTIRTA) angkatan 18, sebanyak 34 mahasiswa menjadi responden dari kuesioner yang disebarkan oleh penulis. Hasil dari pengisian kuesioner responden beserta analisisnya dapat dilihat sebagai berikut :

Tabel 1.

Analisis pernyataan nomor 1

\begin{tabular}{|c|c|}
\hline Pilihan & Persentase \\
\hline Sangat tidak setuju & $0 \%$ \\
\hline Tidak setuju & $2,9 \%$ \\
\hline Cukup setuju & $5,9 \%$ \\
\hline Setuju & $50 \%$ \\
\hline Sangat setuju & $41,2 \%$ \\
\hline Total & $100 \%$ \\
\hline
\end{tabular}

Dari hasil tersebut terlihat bahwa 50\% mahasiswa setuju, 41,2\% sangat setuju dan 5,9 \% cukup setuju dengan pernyataan tersebut. Hanya 2,9\% mahasiswa yang tidak setuju dengan pertanyaan tersebut. Dapat diartikan bahwa sebagian besar mahasiswa menentukan topik informasi yang dibutuhkan sebelum melakukan pencarian informasi.

Tabel 2.

Analisis pernyataan nomor 2

\begin{tabular}{|c|c|}
\hline Pilihan & Persentase \\
\hline Sangat tidak setuju & $0 \%$ \\
\hline Tidak setuju & $2,9 \%$ \\
\hline Cukup setuju & $29,4 \%$ \\
\hline Setuju & $61,8 \%$ \\
\hline Sangat setuju & $5,9 \%$ \\
\hline Total & $100 \%$ \\
\hline
\end{tabular}

Dari hasil tersebut terlihat bahwa 61,8 \% mahasiswa setuju, 29,4 \% cukup setuju dan 5,9 \% sangat setuju dengan pernyataan tersebut. Hanya 2,9\% 
mahasiswa yang tidak setuju dengan pertanyaan tersebut. Dapat diartikan bahwa sebagian besar mahasiswa melakukan pencarian setelah berdiskusi atau berkonsultasi kepada dosen.

Tabel 3

Analisis pernyataan nomor 3

\begin{tabular}{|c|c|}
\hline Pilihan & Persentase \\
\hline Sangat tidak setuju & $0 \%$ \\
\hline Tidak setuju & $2,9 \%$ \\
\hline Cukup setuju & $38,2 \%$ \\
\hline Setuju & $50 \%$ \\
\hline Sangat setuju & $8,9 \%$ \\
\hline Total & $100 \%$ \\
\hline
\end{tabular}

Dari hasil tersebut terlihat bahwa 50\% mahasiswa setuju, 38,2\% cukup setuju dan $8,9 \%$ sangat setuju dengan pernyataan tersebut. Hanya 2,9\% mahasiswa yang tidak setuju dengan pertanyaan tersebut. Dapat diartikan bahwa sebagian besar mahasiswa mengetahui kebutuhan informasinya saat mengikuti pelajaran.

\section{Tabel 4}

Analisis pernyataan nomor 4

\begin{tabular}{|c|c|}
\hline Pilihan & Persentase \\
\hline Sangat tidak setuju & $0 \%$ \\
\hline Tidak setuju & $5,9 \%$ \\
\hline Cukup setuju & $38,2 \%$ \\
\hline Setuju & $44.1 \%$ \\
\hline Sangat setuju & $11,8 \%$ \\
\hline Total & $100 \%$ \\
\hline
\end{tabular}

Dari hasil tersebut terlihat bahwa 44,1\% mahasiswa setuju, 38,2 \% cukup setuju dan $11,8 \%$ sangat setuju dengan pernyataan tersebut. Hanya 5,9\% mahasiswa yang tidak setuju dengan pertanyaan tersebut. Dapat diartikan bahwa sebagian besar mahasiswa mengetahui kebutuhan informasi spesifik atau khusus, informasi yang dibutuhkan berbeda dari orang lain. 
Rifni Raihana, Taufik Asmiyanto, Perilaku Pencarian Informasi Pada ...

Tabel 5

Analisis pernyataan nomor 5

\begin{tabular}{|c|c|}
\hline Pilihan & Persentase \\
\hline Sangat tidak setuju & $0 \%$ \\
\hline Tidak setuju & $0 \%$ \\
\hline Cukup setuju & $17,6 \%$ \\
\hline Setuju & $44.1 \%$ \\
\hline Sangat setuju & $38,2 \%$ \\
\hline Total & $100 \%$ \\
\hline
\end{tabular}

Dari hasil tersebut terlihat bahwa 44,1\% mahasiswa setuju, 38,2 \% sangat setuju dan $17,6 \%$ cukup setuju dengan pernyataan tersebut. Dapat diartikan bahwa mahasiswa melakukan pencarian informasi ketika menyadari dan mengetahui kebutuhan informasi.

Tabel 6

Analisis pernyataan nomor 6

\begin{tabular}{|c|c|}
\hline Pilihan & Persentase \\
\hline Sangat tidak setuju & $0 \%$ \\
\hline Tidak setuju & $5,9 \%$ \\
\hline Cukup setuju & $23,5 \%$ \\
\hline Setuju & $50 \%$ \\
\hline Sangat setuju & $20,6 \%$ \\
\hline Total & $100 \%$ \\
\hline
\end{tabular}

Dari hasil tersebut terlihat bahwa 50\% mahasiswa setuju, 23,5\% cukup setuju dan 20,6 \% sangat setuju dengan pernyataan tersebut. Hanya 5,9\% mahasiswa yang tidak setuju dengan pertanyaan tersebut. Dapat diartikan bahwa sebagian besar mahasiswa melihat daftar pustaka dari penelitian sebelumnya untuk melakukan pencarian informasi. 
Tabel 7

Analisis pernyataan nomor 7

\begin{tabular}{|c|c|}
\hline Pilihan & Persentase \\
\hline Sangat tidak setuju & $0 \%$ \\
\hline Tidak setuju & $14,7 \%$ \\
\hline Cukup setuju & $50 \%$ \\
\hline Setuju & $17,6 \%$ \\
\hline Sangat setuju & $17,6 \%$ \\
\hline Total & $100 \%$ \\
\hline
\end{tabular}

Dari hasil tersebut terlihat bahwa 50\% dari mahasiswa cukup setuju, $17,6 \%$ setuju dan $17,6 \%$ sangat setuju dengan pernyataan tersebut. sebanyak $14,7 \%$ mahasiswa yang tidak setuju dengan pertanyaan tersebut. Dapat diartikan bahwa sebagian besar mahasiswa menggunakan nama pengarang sebagai kata kunci dalam mencari informasi.

Tabel 8

Analisis pernyataan nomor 8

\begin{tabular}{|c|c|}
\hline Pilihan & Persentase \\
\hline Sangat tidak setuju & $0 \%$ \\
\hline Tidak setuju & $0 \%$ \\
\hline Cukup setuju & $2,9 \%$ \\
\hline Setuju & $50 \%$ \\
\hline Sangat setuju & $47,1 \%$ \\
\hline Total & $100 \%$ \\
\hline
\end{tabular}

Dari hasil tersebut terlihat bahwa 50\% mahasiswa setuju, 47,1\% sangat setuju dan 2,9\% cukup setuju dengan pernyataan tersebut. Dapat diartikan bahwa mahasiswa menggunakan subjek/topik sebagai kata kunci dalam pencarian informasi. 
Rifni Raihana, Taufik Asmiyanto, Perilaku Pencarian Informasi Pada ...

Tabel 9

Analisis pernyataan nomor 9

\begin{tabular}{|c|c|}
\hline Pilihan & Persentase \\
\hline Sangat tidak setuju & $2,9 \%$ \\
\hline Tidak setuju & $11,8 \%$ \\
\hline Cukup setuju & $41,2 \%$ \\
\hline Setuju & $41,2 \%$ \\
\hline Sangat setuju & $2,9 \%$ \\
\hline Total & $100 \%$ \\
\hline
\end{tabular}

Dari hasil tersebut terlihat bahwa 41,2 \% mahasiswa setuju dan cukup setuju, serta $2,9 \%$ sangat setuju dengan pernyataan tersebut. 11,8 persen tidak setuju dan 2,9\% sangat tidak setuju dengan pernyataan tersebut. Dapat diartikan bahwa sebagian besar mahasiswa merasa bahwa kebutuhan informasi mereka terpenuhi oleh perpustakaan.

Tabel 10

Analisis pernyataan nomor 10

\begin{tabular}{|c|c|}
\hline Pilihan & Persentase \\
\hline Sangat tidak setuju & $0 \%$ \\
\hline Tidak setuju & $2,9 \%$ \\
\hline Cukup setuju & $0 \%$ \\
\hline Setuju & $35,3 \%$ \\
\hline Sangat setuju & $61,8 \%$ \\
\hline Total & $100 \%$ \\
\hline
\end{tabular}

Dari hasil tersebut terlihat bahwa 61,8 \% mahasiswa sangat setuju dan $35,3 \%$ setuju dengan pernyataan tersebut. Hanya 2,9\% mahasiswa tidak setuju dengan pernyataan tersebut. Dapat diartikan bahwa sebagian besar mahasiswa mencari informasi di internet apabila informasi yang dicari tidak tersedia dalam bentuk tercetak. 
Tabel 11

Analisis pernyataan nomor 11

\begin{tabular}{|c|c|}
\hline Pilihan & Persentase \\
\hline Sangat tidak setuju & $0 \%$ \\
\hline Tidak setuju & $20,6 \%$ \\
\hline Cukup setuju & $44,1 \%$ \\
\hline Setuju & $32,4 \%$ \\
\hline Sangat setuju & $2,9 \%$ \\
\hline Total & $100 \%$ \\
\hline
\end{tabular}

Dari hasil tersebut terlihat bahwa 44,1 \% mahasiswa cukup setuju, 32,4\% setuju dan 2,9\% sangat setuju pernyataan tersebut. 20,6\% mahasiswa tidak setuju dengan pernyataan tersebut. Dapat diartikan bahwa sebagian besar mahasiswa lebih sering menggunakan informasi yang tercetak/print.

\section{Tabel 12}

Analisis pernyataann nomor 12

\begin{tabular}{|c|c|}
\hline Pilihan & Persentase \\
\hline Sangat tidak setuju & $0 \%$ \\
\hline Tidak setuju & $0 \%$ \\
\hline Cukup setuju & $2,9 \%$ \\
\hline Setuju & $44,1 \%$ \\
\hline Sangat setuju & $52,9 \%$ \\
\hline Total & $100 \%$ \\
\hline
\end{tabular}

Dari hasil tersebut terlihat bahwa 52,9 \% mahasiswa sangat setuju, 44,1\% setuju dan 2,9\% cukup setuju dengan pernyataan tersebut. Dapat diartikan bahwa mahasiswa membaca terlebih dahulu informasi yang diperoleh sebelum mengutip.

Tabel 13

Analisis pernyataan nomor 13

\begin{tabular}{|c|c|}
\hline Pilihan & Persentase \\
\hline Sangat tidak setuju & $0 \%$ \\
\hline Tidak setuju & $0 \%$ \\
\hline Cukup setuju & $2,9 \%$ \\
\hline Setuju & $44,1 \%$ \\
\hline Sangat setuju & $52,9 \%$ \\
\hline Total & $100 \%$ \\
\hline
\end{tabular}


Rifni Raihana, Taufik Asmiyanto, Perilaku Pencarian Informasi Pada ...

Dari hasil tersebut terlihat bahwa 52,9 \% mahasiswa sangat setuju, 44,1\% setuju dan 2,9\% cukup setuju dengan pernyataan tersebut. Dapat diartikan bahwa mahasiswa menyeleksi terlebih dahulu informasi yang diperoleh sebelum mengutip.

Tabel 14

Analisis pernyataan nomor 14

\begin{tabular}{|c|c|}
\hline Pilihan & Persentase \\
\hline Sangat tidak setuju & $0 \%$ \\
\hline Tidak setuju & $0 \%$ \\
\hline Cukup setuju & $14,7 \%$ \\
\hline Setuju & $58,8 \%$ \\
\hline Sangat setuju & $26,5 \%$ \\
\hline Total & $100 \%$ \\
\hline
\end{tabular}

Dari hasil tersebut terlihat bahwa 58,8 \% mahasiswa setuju, 26,5\% setuju dan $14,7 \%$ cukup setuju dengan pernyataan tersebut. Dapat diartikan bahwa mahasiswa selalu mencari informasi yang terbaru.

Dari analisis jawaban kuesioner diatas terlihat bahwa mahasiswa pendidikan biologi angkatan 18 UNTIRTA memiliki kebutuhan informasi dan melakukan pencarian informasi. mahasiswa pendidikan biologi angkatan 18 UNTIRTA melakukan pencarian informasi ketika merasa butuh terhadap suatu informasi. karena berada di lingkungan akademis, sebagian besar kebutuhan informasi adalah untuk menyelesaikan tugas atau penelitian. Oleh sebab itu, sebagian besar mahasiswa melakukan konsultasi/diskusi dengan dosen sebelum melakukan pencarian informasi. Uraian perilaku pencarian informasi dari mahasiswa pendidikan biologi angkatan 18 UNTIRTA adalah sebagai berikut :

1. Starting : terdiri dari kegiatan atau aktivitas yang memulai terjadinya kegiatan pencarian informasi. Dari hasil analisis kuesioner terlihat bahwa mayoritas mahasiswa pendidikan biologi angkatan 18 UNTIRTA menentukan topik dari kebutuhan informasi sebelum melakukan pencarian. Selain itu, mahasiswa juga berdiskusi/konsultasi dengan dosen sebelum melakukan pencarian informasi. 
2. Chaining : kegiatan mengikuti rangkaian sitasi, pengutipan atau bentuk-bentuk perujukan antar dokumen yang satu dengan yang lainnya. Dari hasil analisis kuesioner bahwa mayoritas mahasiswa pendidikan biologi angkatan 18 UNTIRTA merujuk daftar pustaka penelitian terdahulu sebelum melaksanakan pencarian informasi.

3. Browsing : pencarian secara acak, mencari tetapi dengan agak terarah, di wilayah-wilayah yang dianggap punya potensi terhadap informasi yang dibutuhkan. Dari hasil analisis kuesioner terlihat bahwa mahasiswa memiliki kata kunci atau keywords dalam melakukan pencarian. Mayoritas mahasiswa menggunanakan topik/subjek dan nama penulis sebagai kata kunci guna menemukan informasi yang dibutuhkan. Mahasiswa melakukan pencarian infromasi di perpustakaan, karena merasa kebutuhan informasinya mampu terpenuhi. Akan tetapi, mahasiswa akan mencari versi digital atau melakukan pencarian online apabila informasi tercetak tidak tersedia.

4. Differentiating : pemilahan, menggunakan ciri-ciri di dalam sumber informasi sebagai acuan dasar untuk memeriksa kualitas ataupun isi informasi. Dari hasil analisis kuesioner terlihat bahwa mahasiswa pendidikan biologi angkatan 18 UNTIRTA melakukan pemilahan informasi karena sebagian besar mahasiswa membaca terlebih dahulu informasi yang didapatkan sebelum mengutip.

5. Monitoring : memantau perkembangan dengan memfokuskan diri pada beberapa sumber terpilih. Dari hasil analisis kuesioner terlihat bahwa mahasiswa pendidikan biologi angkatan 18 UNTIRTA melakukan monitoring karena berdasarkan analisis dari kuesioner bahwa sebagian besar mahasiswa pendidikan biologi angkatan 18 UNTIRTA mencari informasi yang terbaru. Artinya mahasiswa memantau perkebangan dan bertujuan untuk menggunakan informasi yang terbaru.

6. Extracting : secara sistematis menggali di satu sumber untuk mengambil informasi yang dianggap penting. Dari hasil analisis kuesioner terlihat bahwa mahasiswa pendidikan biologi angkatan 18 UNTIRTA melakukan extracting karena berdasarkan analisis dari kuesioner bahwa sebagian besar mahasiswa 
Rifni Raihana, Taufik Asmiyanto, Perilaku Pencarian Informasi Pada ...

pendidikan biologi angkatan 18 UNTIRTA mengimpelementasikan seleksi informasi sebelum mengutip

\section{PENUTUP}

Berdasarkan hasil analisis kuesioner dapat disimpulkan bahwa mahasiswa pendidikan biologi angkatan 18 UNTIRTA telah memahami kebutuhan informasinya. Baik informasii secara umum maupun kebutuhan informasi spesifiknya. Karena berada di lingkungan akademis, inforomasi sangat diperlukan oleh mahasiswa guna menyelesaikan tugas atau penelitiannya. Mahasiswa melaksanakan seluruh model perilaku pencarian informasi mulai dari starting hingga extracting. Pada tahap starting mahasiswa melakukan diskusi atau konsultasi dengan dosen terkait serta menyiapkan topik/kata kunci sebelum memulai pencarian. Pada tahap chaining mahasiswa melihat daftar pustaka pada penelitian sebelumnya sebagai rujukan guna mempermudah proses pencarian. Selanjutnya mahasiswa mulai melakukan browsing. Mahasiswa pergi ke perpustakaan untuk mencari informasi tercetak. Apabila informasi tercetak tidak tersedia, maka mahasiswa melakukan pencarian dalam bentuk online.

Setelah melakukan browsing, mahasiswa melakukan differentiating. Mahasiswa membaca hasil temuannya. Hal ini bertujuan untuk menyesuaikan informasi yang diterim adengan yang dibutuhkan. Apabila tidak sesuai, tentunya informasi tersebut tidak digunakan. Jadi, dalam proses ini terdapat aktivitas seleksi informasi. Setelah itu, mahasiswa melakukan monitoring. Mahasiswa memantau informasi yang diterima sekaligus melihat perkembangan dari topiknya. Mahasiswa pendidikan biologi angkatan 18 berusaha mencari dan menggunakan informasi yang terbaru. Tahap terakhir adalah extracting. Mahasiswa membaca dan mengutip dari informasi hasil pencariannya. Dapat disimpulkan bahwa mahasiswa pendidikan biologi angkatan 18 UNTIRTA memiliki kesadaraan akan kebuutuhan informasi dan mampu mencari, memilah dan mengolah informasi sesuai dengan kebutuhannya. 


\section{DAFTAR RUJUKAN}

Alwi, Idrus. "Kriteria Empirik Dalam Menentukan Ukuran Sampel Pada Pengujian Hipotesis Statistika Dan Analisis Butir." Formatif: Jurnal Ilmiah Pendidikan MIPA 2, no. 2 (August 5, 2015). https://doi.org/10.30998/formatif.v2i2.95.

Bhatt, Atul Ashokbhai. "Information Needs, Perceptions and Quests of Law Faculty in the Digital Era." Electronic Library 32, no. 5 (2014): 659-69. https://doi.org/10.1108/EL-11-2012-0152.

Hanif, Luthfi, and Ika Krismayani. "Relevansi Ketersediaan Koleksi Terhadap Pemenuhan Kebutuhan Informasi Mahasiswa Di Perpustakaan Pusat Universitas Pgri Semarang." Jurnal Ilmu Perpustakaan 7, no. 2 (2018): 20110. https://ejournal3.undip.ac.id/index.php/jip/article/view/22905.

Latiar, Hadira. "Analisis Kebutuhan Dan Perilaku Pencarian Informasi Mahasiswa Difabel UIN Sunan Kalijaga Yogyakarta." LIBRARIA: Jurnal Perpustakaan 6, no. 2 (December 13, 2018): 239. https://doi.org/10.21043/libraria.v6i2.2767.

Mansour, Essam. "Profiling Information Needs and Behaviour of Syrian Refugees Displaced to Egypt: An Exploratory Study." Information and Learning Science 119, no. 3-4 (2018): 161-82. https://doi.org/10.1108/ILS-08-20170088.

Rahma Ningrum, Dina, Choirul Saleh, and Widia Permana Jurusan Administras Publik. "PENGARUH KEBUTUHAN INFORMASI PEMUSTAKA TERHADAP PENGEMBANGAN KOLEKSI BUKU TERCETAK PADA PERPUSTAKAAN UNIVERSITAS BRAWIJAYA (Studi Pada Mahasiswa S1 Jurusan Administrasi Publik Universitas Brawijaya)." Jap) 3, no. 5 (n.d.): 782.

http://administrasipublik.studentjournal.ub.ac.id/index.php/jap/article/view/8 65.

Rahmadi, Imam Fitri, Khaerudin Khaerudin, and Cecep Kustandi. "Kebutuhan Sumber Belajar Mahasiswa Yang Mendukung Pembelajaran Berbasis Teknologi Informasi Dan Komunikasi Di Perguruan Tinggi." JTP - Jurnal Teknologi Pendidikan 20, no. 2 (2018): 120-36. https://doi.org/10.21009/jtp.v20i2.8620.

Rahmah, Yuni, and Elva Rahmah. "Perilaku Pencarian Informasi Generasi Milenial Untuk Memenuhi Kebutuhan Informasi Mahasiswa Universitas Negeri Padang." Ilmu Informasi Perpustakaan Dan Kearsipan 8, no. 1 (October 29, 2019): 562. https://doi.org/10.24036/107488-0934.

Savolainen, Reijo. "Expectancy-Value Beliefs and Information Needs as Motivators for Task-Based Information Seeking." Journal of Documentation 68, no. 4 (2012): 492-511. https://doi.org/10.1108/00220411211239075.

Tawaf; Khaidir, Alimin. "Kebutuhan Informasi Manusia: Sebuah Pendekatan Kepustakaan." Kutubkhanah 15, no. 1 (June 2, 2012): 50-59. http://ejournal.uin-suska.ac.id/index.php/Kutubkhanah/article/view/249. 